\title{
Correction to: Revefenacin: First Global Approval
}

Young-A Heo ${ }^{1}$

Published online: 29 March 2019

(c) Springer Nature 2019

\section{Correction to: Drugs (2019) 79:85-91}

https://doi.org/10.1007/s40265-018-1036-x

The article Revefenacin: First Global Approval, written by Young-A Heo, was originally published Online First without open access. After publication in volume 79, issue 1, pages 85-91, Mylan Inc. (Canonsburg, Pennsylvania, USA) and Theravance Biopharma US, Inc. (South San Francisco, California, USA) requested that the article be Open Choice to make the article an open access publication. Post-publication open access was funded by Mylan Inc. (Canonsburg, Pennsylvania, USA) and Theravance Biopharma US, Inc. (South San Francisco, California, USA). The article is forthwith distributed under the terms of the Creative Commons Attribution-NonCommercial 4.0 International License (http:// creativecommons.org/licenses/by-nc/4.0/), which permits any noncommercial use, duplication, adaptation, distribution and reproduction in any medium or format, as long as you give appropriate credit to the original author(s) and the source, provide a link to the Creative Commons license and indicate if changes were made.

The original article has been corrected.

Open Access This article is distributed under the terms of the Creative Commons Attribution-NonCommercial 4.0 International License (http://creativecommons.org/licenses/by-nc/4.0/), which permits any noncommercial use, distribution, and reproduction in any medium, provided you give appropriate credit to the original author(s) and the source, provide a link to the Creative Commons license, and indicate if changes were made.
The original article can be found online at https://doi.org/10.1007/ s40265-018-1036-x.

Young-A Heo

dru@adis.com

1 Springer, Private Bag 65901, Mairangi Bay, Auckland 0754, New Zealand 